\title{
Effect of Physical Exercise Program on Psychotic Symptoms and Social Functioning of Patients with Schizophrenia
}

\author{
Mahmoud Mohamed Abd El-Wahab Khedr, Assistant Lecturer \\ Psychiatric Nursing and Mental Health, Faculty of Nursing, Alexandria University \\ Mervat Mostafa El-Gueneidy, Professor \\ Psychiatric Nursing and Mental Health, Faculty of Nursing, Alexandria University
}

Amal Mohamed Gamal Eldin Shehata, Professor

Psychiatric Nursing and Mental Health, Faculty of Nursing, Alexandria University

\author{
Mohamed Mohamed Ali Elkot, Assistant Professor \\ Exercises and Gymnastics Training, Faculty of Sports Education for Men, Alexandria \\ University
}

\begin{abstract}
Schizophrenia stands as one of the top 10 leading causes of disability in the world and it is often associated with hospitalization, inadequate treatment and relapse. Physical exercise program is an innovative treatment which may have positive effects on patients with schizophrenia offering a possible adjunctive intervention which may improve both psychotic symptoms and social functioning. Objective: Determine the effect of applying physical exercise program on psychotic symptoms and social functioning of patients with schizophrenia. Setting: The psychiatric inpatient wards of ELMaamoura Hospital for Psychiatric Medicine. Subjects: Seventy (70) randomly selected male patients with schizophrenia were included in this study. Tools: Three tools were used; socio-demographic and clinical data tool, the Brief Psychiatric Rating Scale (BPRS-version 4.0) and the Social Functioning Scale (SFS). In addition, physical exercise program intervention was designed and implemented. Results: The findings revealed that overall psychotic symptoms were significantly improved immediately and after three months of applying the physical exercise program. Also, the results showed significant improvement in social functioning subscales (withdrawal\& social engagement, interpersonal communication, independence-competence, recreation and pro social subscale) among the studied patients. Conclusion: Physical exercises have a positive effect on psychotic symptoms and specific social functioning areas. Recommendations: Physical exercise training program should be considered as an integral part in the hospital routine of patients with schizophrenia.
\end{abstract}

Keywords: Physical exercise; Psychotic symptoms; Social functioning; Schizophrenia.

\section{Introduction}

Schizophrenia is a severe and chronic form of mental illness that affects about $1 \%$ of the world's population. It is ranked as one of the top ten leading causes of disability and there is no country where schizophrenia does not exist ${ }^{(1)}$. The incidence and prevalence figures for schizophrenia in Egypt do not differ from those found in other parts of the world. It is estimated that the number of persons with schizophrenia in Egypt would be within $0.5-1.5$ million and from 10000-25000 new patients with schizophrenia appear yearly ${ }^{(2)}$.

Impaired social functioning is considered as one of the negative symptoms and essential feature of schizophrenia in both DSM-V and ICD-11 classifications of mental disorders ${ }^{(3,4)}$. Until today, numerous factors such as symptom severity, neurocognitive impairments, and social cognitive deficits have been attributed to the social impairments seen in patients with schizophrenia $^{(5)}$. This impairment is defined as the inability of individuals to meet societal defined roles such as homemaker, 
worker, student, spouse, family member or friend. In addition, individuals' satisfaction with their ability to meet these roles, their ability to care for themselves and the extent of their leisure and recreational activities often subsumed under the rubric of social functioning, are also impaired ${ }^{(6)}$.

Since schizophrenia may not be a single condition and its causes are not yet known, there are multiple modalities used in the treatment of this disorder. Antipsychotic medications are considered as an important form of these modalities. These medications reduce the psychotic symptoms of schizophrenia and may allow the patient to function more effectively and appropriately $^{(7)}$. For a long time, it was believed that antipsychotic medications are the only effective method for treating schizophrenia, yet it was found that they do not "cure" schizophrenia or ensure that there will be no further psychotic episodes ${ }^{(8)}$.

Physical exercise is one of the psychosocial interventions considered as possible effective adjunctive intervention which may improve physical health, mental health and social functions of patients with schizophrenia $^{(9)}$. As patients with schizophrenia tend to be more sedentary compared to the general population, increasing level of physical activity of these patients seem essential, and also an easy method for preventing or minimizing the many health problems associated with sedentary lifestyle and reducing mortality ${ }^{(10)}$.

Moreover, research has showed that more physically active people tend to be less affected by mental disorders than sedentary people ${ }^{(11)}$. It was also found that physical exercise promotes numerous benefits in mental health. These benefits are caused by biological factors that connect changes that occur during and after completing an exercise. Therefore, there seems to be an interesting relationship between the amount of exercise performed and the prevalence of severe mental disorders such as schizophrenia ${ }^{(11,12)}$. Thus due to the positive mental and physical effects of exercise, it can play a vital role in rehabilitation and treatment of psychotic patients ${ }^{(13)}$.

Mental health nurses have a crucial role to play in the care of schizophrenic patients. They are in frequent and prolonged contact with the patient and family members. This intense contact is an important pre requisite for the success of intervention. They can assume the role of consultant, supporter and caregiver in the rehabilitation team ${ }^{(14)}$. Few studies have looked directly to the benefits of physical activity for mental health consumers and whether promoting physical activity is part of the role of nurses in mental health care settings ${ }^{(15)}$. In this regard, the present study aims to determine the effect of applying physical exercises on psychotic symptoms and social functioning of patients with schizophrenia.

\section{Aim of the Study}

This study aims to determine the effect of implementing physical exercise program on psychotic symptoms and social functioning of patients with schizophrenia.

\section{Research Hypothesis}

Patients with schizophrenia who are exposed to the physical exercise program exhibit less psychotic symptoms and improved social functioning than those who are not exposed to such program.

\section{Materials and Method}

\section{Materials}

Design: A quasi experimental research design was utilized in this study.

Setting: The study was conducted in the psychiatric inpatient wards of EL-Maamoura Hospital for Psychiatric Medicine affiliated to the Ministry of Health and population. It serves three governorates namely Alexandria, Matrouh, and El-Beheira.

Subjects: Seventy randomly selected male patients with schizophrenia constituted the study subjects. They were divided equally 
into two groups (study and a control group) matched as much as possible. They were selected according to the following inclusion criteria:

1) Male patients diagnosed with schizophrenia with no co-morbidity.

2) Physically fit and able to communicate coherently and relevantly.

3) Duration of illness not exceeding 10 years.

4) Recently admitted ( $2-3$ weeks) "to ensure the continuity of being in contact with the community".

Tools: Data of the present study were collected using the following tools:

Tool I: A Socio-Demographic and Clinical Data Tool

This tool was developed to collect data about the study subjects' characteristics as age, marital status, education level, the duration of illness, age of onset of the disease and number of psychiatric hospitalization.

\section{Tool II: The Brief Psychiatric Rating} Scale (BPRS- version 4.0)

The $4^{\text {th }}$ version of the brief psychiatric rating scale was developed by Ventura et al $(1993)^{(16)}$. It is composed of 24 items probing each symptom of psychiatric disorder. These items also provide supplementary rules for rating and the anchor points are well defined. Additional guidelines for interviews and operational definitions regarding the frequency of symptoms and social functioning alterations are available ${ }^{(17)}$.

The presence and severity of psychiatric symptoms are rated on a 7 point Likert scale ranging from 1 (not present) to 7 (extremely severe). Thus, possible scores vary from 24 to 168 , with lower scores indicating less severe psychopathology. The items from 1 to 14 are rated by a self-report measure (from patients), while items from 15 to 24 are rated by observation. Items 7,12 and 13 are rated by both self-report and observation measures $^{(16)}$.

BPRS items are divided to four groups including positive symptoms, negative symptoms, depression- anxiety, and agitation-mania. In addition, four symptoms related to somatic concern, hostility, elevated mood and self-neglect are added to the above groups ${ }^{(18)}$.

\section{Tool III: The Social Functioning Scale} $\underline{\text { (SFS) }}$

This was developed by Birchwood et al (1990) to assess social skills and performance, and cover functions that are of importance for patients suffering from schizophrenia $^{(19)}$.

The SFS is a self-administered questionnaire and consists of 79 items with varying response format (dichotomous questions, three point likert scale, four point likert scale and five point likert scale). These items are classified into seven subscales; withdrawal/social engagement) 5 items), interpersonal communication (4 items), independence-performance (13 items), independence-competence (13 items), recreation (15 items), prosocial activities (22 items), and employment/occupation (5 items), in addition to two unscored preliminary questions. The SFS total score ranged from 0 to 223 and was successfully used on Egyptian patients with schizophrenia in previous studies ${ }^{(20,21)}$.

\section{Method}

\section{I- Administrative steps:}

- Official written permissions were obtained from the general secretariat for mental health at the Ministry of Health and Population in Cairo and from the director of El-Maamoura Hospital for Psychiatric Medicine in Alexandria.

\section{II- Pilot study:}

- Before starting the actual study, a pilot study was carried out on 10 patients diagnosed with schizophrenia. 


\section{III- Actual study:}

- Prior to the study, the researcher received training on physical exercises for a period of 2 months under the supervision of professional expert in the field of physical exercises at the Faculty of Sports Education for Men, Alexandria University.

- Psychotic male patients' wards were randomly selected using simple random sampling technique. The first selected ward was assigned for the first small study group and its control group. The second selected ward was assigned for the second study and control group and so on.

- Patients' medical charts in the selected wards were reviewed to identify those who meet the inclusion criteria. Study patients were recruited using simple random technique from those meeting the inclusion criteria.

- A medical checkup was performed for patients in the study group to exclude any contraindications for carrying out physical exercise.

- The study group (35 patients) was divided into 7 small groups of 5 patients each.

- Patients from the study and control groups were interviewed individually by the researcher to apply tool III (SFS). Also they were interviewed and observed by the researcher to apply tool II (BPRS). Observation was carried out for one hour/day for two consecutive days before any interventions.

- Physical exercises were performed for patients in the study group while those in the control group were left to undergo the usual hospital routine. The physical exercise intervention phase took three weeks for each patient (three sessions per week for three weeks - Nine sessions for each group). It was applied for two groups each week for three weeks (one group/day - 3 sessions/week for each group - six days/week for the two groups).

- Patients' addresses and telephone numbers were kept in confidential notebook by the researcher after taking their permission to facilitate follow up of patients and collect data after intervention.

- After termination of the physical exercise program, every patient in both groups was interviewed and observed using tool II (BPRS). In addition, after three months of discharge, patients in both groups were interviewed and observed using tool II (BPRS) and tool III (SFS) at the outpatient clinic.

- The period of data collection was about 10 Months from (May 2018 to February 2019). Although 15 patients were added to the total number of patients (10 patients were added to the study group and 5 patients were added to the control group) to substitute the number of patients who didn't complete the research.

\section{Physical Exercise Program:}

- Physical exercise program is an innovative exercise programconsisting of three basic parts (warm up - physical fitness - cool down). It was developed under the supervision of experienced trainer of physical exercise. In each part of the program, there is a specific time for practicing these exercises in front of the patients to teach them and also time for practicing it by patients.

- Warm up part of intervention consists of 3 physical stretching and bending movements, while physical fitness part consists of 6 physical exercises of rapid walking accompanied by a variety of arm and leg movements. Finally cool down part consists of 2 physical exercises similar to that of 
warm up part. In addition, all exercises in all parts could be modified from one day to another and could be repeated several times by patients with specific difficulty according to each activity.

- A pleasant, supportive, and enthusiastic atmosphere was maintained during the physical exercises phase. Slow and restful music was played during warm up and cool-down and popular music with a fast beat was played during the main portion of the exercise.

- Different materials were used to help in completing the exercises and attracting the patient as white powder to determine area of exercise, and colorful balls

\section{Ethical considerations:}

Patients were informed about the purpose of the study and an informed written consent was obtained. Also they were told that they have the right to refuse or withdraw from the study at any time even after starting the session. Patients' privacy and data confidentiality were assured and maintained.

\section{Statistical Analysis}

Data were analyzed using IBM SPSS software package version 20.0. Qualitative data were described using number and percent. Quantitative data were described using range, mean, standard deviation. Significance of the obtained results was judged at the $5 \%$ level.

For categorical variables and to compare between different groups, chi- square test was used. Monte Carlo correction used for chi-square when more than $20 \%$ of the cells have expected count less than 5. Also McNemar Test was used to analyze the significance between the different stages. For abnormally distributed quantitative variables and to compare between two studied groups, Mann Whitney test was used. In addition, Wilcoxon signed ranks test used for abnormally distributed quantitative variables and to compare between two periods. Finally, Friedman test used for abnormally distributed quantitative variables, to compare between more than two periods or stages.

\section{Results}

Table (1) shows the socio demographic characteristics of studied patients with schizophrenia and their control group. Regarding age group, $71.4 \%$ of the study group and $65.7 \%$ of the control were between 21 to less than 31 years. Single patients constituted $65.7 \%$ and $74.3 \%$ of the study and control group, respectively. Illiterate patients represent $40 \%$ of the study group and $45.7 \%$ of the control group, while those who were highly educated represent $17.1 \%$ of the study group and $14.3 \%$ of the control group.

An equal percentage $(68.6 \%)$ of both the study and control groups were living in urban areas. Unemployed patients represented $48.6 \%$ of the study group and $42.9 \%$ of the control one. More than one half $(62.9 \%)$ of the study group and nearly three quarters of the control group $(74.3 \%)$ were living with their family. In relation to family size, patients from family ranging from 4 to 6 members constituted $48.6 \%$ of the study group and $57.1 \%$ of the control group. Regarding income, $74.3 \%$ of the study group and $71.4 \%$ of the control group considered their income as insufficient. The source of income for both the study and control group was derived firstly from work $(45.7 \%)$. The table also shows that $71.4 \%$ of both study and control groups were selected from free departments.

Table (2) shows the clinical characteristics of studied patients with schizophrenia and their control group. The duration of psychiatric disorder ranged between 2 to 5 years for $45.7 \%$ of patients in the study group and $42.9 \%$ for those on the control. Patients currently hospitalized for less than 2 weeks represented $65.7 \%$ of the study group and $71.4 \%$ of the control group. 
Among the study group, $51.4 \%$ were treated by psychotropic medications from 2 years to 5 years compared to $42.9 \%$ of the control group. In addition, more than one third of both the study and control groups have been admitted for three times to six times $(40 \%$ and $42.9 \%$ respectively).

The most common symptom present on admission among both the study and control groups was hallucinations. Among the study group, $42.9 \%$ of patients were discharged since less than 6 months, and $51.4 \%$ of the control group were discharged since 6 months to less than one year. Typical antipsychotics were the most frequent prescription for the study and control groups (48.6\% and $51.4 \%$ respectively).

Table (3) presents means obtained in total social functioning scale (SFS) and its subscales for studied patients with schizophrenia and their control groups in pre and post intervention periods. A statistically significant difference was found after implementing the program between the study and control group in total SFS and in certain of its subscales (withdrawal\& social engagement $\quad(p=0.047), \quad$ interpersonal communication $(\mathrm{p}=0.035)$, independencecompetence $(\mathrm{p}=0.025)$, recreation $(0.040)$ and prosocial subscale (0.035). Conversely, there were no statistical significant difference after implementing the program between both the study and control group in relation to independence-performance and employment\& occupation subscales (p>0.05).

Table (4) illustrates the comparison between the studied and control groups according to positive symptoms in pre and post intervention periods. A statistically significant difference between study and control groups was found after three months of intervention in total positive symptoms group $(\mathrm{p}=0.042)$, grandiosity $(\mathrm{p}=0.044)$, and unusual thought content (0.008). Test of significance proved no statistically significant difference after three months of intervention between both groups in certain symptoms which include bizarre behavior
(0.167), disorientation (0.710), hallucinations (0.197), suspiciousness (0.537), and conceptual disorganization (0.543).

Table (5) illustrates the comparison between the studied and control groups according to negative symptoms group on the brief psychiatric rating scale (BPRS) at pre and post intervention periods. The table revealed a statistically significant difference between study and control groups in total negative symptoms group $(\mathrm{p}=0.005)$, blunted affect $(\mathrm{p}=0.033)$, emotional withdrawal (0.031), motor retardation (0.004) after three months of intervention.

\section{Discussion}

Schizophrenia is a prototypical brain disorder that affects and affected by the social environment ${ }^{(22)}$. Impairment in social functioning is a central feature of schizophrenia and is known to be evident before the onset of psychosis, acting as a potential vulnerability marker ${ }^{(23)}$. Moreover, social dysfunctions and psychotic symptoms are considered significant criteria needed for diagnosis of schizophrenia according to Diagnostic and Statistical Manual of Mental Disorders (DSM-5) ${ }^{(24)}$.

Patients with schizophrenia have less active lifestyles than the general population $^{(25)}$. So that, physical exercise is needed in patients' program of treatment. It considered as an alternative treatment, which could play a pivotal role in enhancing patients' physical and mental health. Moreover, there has been a growing interest in investigating the relationship between physical exercises and symptoms of schizophrenia $^{(26)}$. Physical exercise is considered as adjunctive nonpharmacological treatment modality that could be used also to tackle symptoms of schizophrenia ${ }^{(9)}$. Randomized intervention studies examining the effect of exercise on psychotic symptoms have been inconclusive. Some studies ${ }^{(9,27)}$ report a beneficial effect on these symptoms while others do not ${ }^{(28,29)}$. The present study was carried out to 
determine the effect of applying physical exercises on social functioning and psychotic symptoms of patients with schizophrenia.

The results of the current study revealed a statistically significant difference between study and control groups after implementation of physical exercise program in total social functioning. This result may be attributed to the neurobiological effect of physical exercise on the brain of patients with schizophrenia which can ameliorate abnormalities in schizophrenia including their social dysfunction. Also doing physical exercises in group also can enhance communication and socialization among these patients.

These results were supported by previous research that revealed positive effects of physical exercise on social functioning and social cognition among patients with schizophrenia ${ }^{(30,31)}$. In this respect, Kandola et al. (2016) also explain this effect of physical exercise on social functioning as stating that exercises stimulate the brain in a way that might normalize neural alterations related to the disorder ${ }^{(32)}$.

$$
\text { elimination }^{(35)} \text {. }
$$

The results of the current study revealed that statistically significant difference was found after three months of intervention between both groups in the total negative symptoms, where they improved significantly among the study group than the control group. This could be due to the effect of exercise on improvement of motivation and selfesteem of patients with schizophrenia and hence their negative symptoms ${ }^{(36)}$. This also could be attributed to the benefits which come from changes in the brain's chemistry brought about by increased physical exercises.

Consistent with the present findings, Wang et al. (2018) found that exercises can improve negative symptoms and general psychopathology during the period of intervention and further improve negative symptoms during the 3-month follow-up period in patients with schizophrenia receiving antipsychotic treatment ${ }^{(37)}$. In the same line, further studies found that physical exercises have significant positive effects in reducing severity of negative symptoms among patients with schizophrenia $^{(30,38,39)}$. Millan (2014) reported that dysfunction of glutamate is the cause of appearance of negative symptoms in schizophrenia and increasing glutamate in the brain may be the mechanism by which physical exercise can reduce negative symptoms ${ }^{(40)}$.

Conversely to the present findings, Vogel et al. (2015) reviewed studies of the effects of
The current study results showed that statistically significant difference was found after three months of intervention between both groups in the total positive symptoms, where they improved significantly among the study group than the control group. This may be attributed to neurobiological effect of the exercises on the brain of patients with schizophrenia. Another explanation for this result is the effectiveness of physical exercises in helping patients to be in contact with reality and detached from hallucinations and delusions.

Similarly, Stranahan et al. (2008) and Vina et al. (2012) explain the effect of exercises on positive symptoms by its effectiveness to increase the levels of brain-derived neurotropic factors, and also to correct dysfunction of the hypothalamicpituitary-adrenal system $^{(33,34)}$. Khazaeinia et al. (2000) reported that one of the possible ways in which exercises might improve symptoms of schizophrenia is that exercise may increase the drug level by changing the pharmacokinetics of antipsychotics, e.g., changing the drug distribution or reducing drug exercise on negative symptoms of schizophrenia and concluded that this could not be confirmed ${ }^{(41)}$. Also Lutgens et al. (2017) reported that psychological and psychosocial treatments show small to moderate effects on negative symptoms of schizophrenia $^{(42)}$.

\section{Conclusion}

Physical exercises have a positive effect on psychotic symptoms and specific social functioning areas.

\section{Recommendations}

Based on the findings of the current study, the following recommendations have been generated:

- Physical exercise training program should be considered as an integral part of the hospital routine for patients with schizophrenia.

- Caregivers should be taught about the importance of this program and how to apply it for patients with schizophrenia.

- Physical training program for patients with schizophrenia has to be conducted at other different psychiatric hospitals in other Governorates.

- A pleasant, supportive, and enthusiastic atmosphere needs to be maintained to promote social interaction and motivate physical exercise. 
Table (1): Socio demographic characteristics of study subjects with schizophrenia and their control group

\begin{tabular}{|c|c|c|c|c|c|c|}
\hline \multirow[t]{2}{*}{ Socio demographic characteristics } & \multicolumn{2}{|c|}{$\begin{array}{c}\text { Study } \\
(\mathbf{n}=\mathbf{3 5})\end{array}$} & \multicolumn{2}{|c|}{$\begin{array}{c}\text { Control } \\
(\mathbf{n}=35)\end{array}$} & \multirow[t]{2}{*}{$\chi^{2}$} & \multirow[t]{2}{*}{$\mathbf{p}$} \\
\hline & No. & $\%$ & No. & $\%$ & & \\
\hline $\begin{array}{l}\text { Age } \\
<21 \\
21<31 \\
31<41 \\
\end{array}$ & $\begin{array}{c}4 \\
25 \\
6\end{array}$ & $\begin{array}{l}11.4 \\
71.4 \\
17.1\end{array}$ & $\begin{array}{c}5 \\
23 \\
7 \\
\end{array}$ & $\begin{array}{l}14.3 \\
65.7 \\
20.0\end{array}$ & 0.350 & $\begin{array}{l}{ }_{\mathrm{p}}^{\mathrm{MC}}= \\
0.876\end{array}$ \\
\hline $\begin{array}{l}\text { Marital status } \\
\text { Single } \\
\text { Married } \\
\text { Divorced/widowed }\end{array}$ & $\begin{array}{c}23 \\
7 \\
5 \\
\end{array}$ & $\begin{array}{l}65.7 \\
20.0 \\
14.3\end{array}$ & $\begin{array}{c}26 \\
6 \\
3 \\
\end{array}$ & $\begin{array}{c}74.3 \\
17.1 \\
8.6\end{array}$ & 0.802 & $\begin{array}{l}{ }^{\mathrm{MC}} \mathrm{p}= \\
0.747\end{array}$ \\
\hline $\begin{array}{l}\text { Level of education } \\
\text { Illiterate } \\
\text { Read and write } \\
\text { Primary } \\
\text { Preparatory } \\
\text { Secondary } \\
\text { Highly educated } \\
\end{array}$ & $\begin{array}{c}14 \\
1 \\
2 \\
3 \\
9 \\
6\end{array}$ & $\begin{array}{c}40.0 \\
2.9 \\
5.7 \\
8.6 \\
25.7 \\
17.1 \\
\end{array}$ & $\begin{array}{l}16 \\
2 \\
2 \\
2 \\
8 \\
5\end{array}$ & $\begin{array}{c}45.7 \\
5.7 \\
5.7 \\
5.7 \\
22.9 \\
14.3 \\
\end{array}$ & 1.153 & 0.984 \\
\hline $\begin{array}{l}\text { Place of residence } \\
\text { Urban } \\
\text { Rural }\end{array}$ & $\begin{array}{l}24 \\
11 \\
\end{array}$ & $\begin{array}{l}68.6 \\
31.4 \\
\end{array}$ & $\begin{array}{l}24 \\
11\end{array}$ & $\begin{array}{l}68.6 \\
31.4 \\
\end{array}$ & 0.00 & 1.000 \\
\hline $\begin{array}{l}\text { Occupation } \\
\text { Unemployed } \\
\text { Employee } \\
\text { worker } \\
\text { Trader } \\
\text { Non worker } \\
\text { Student } \\
\text { On pension }\end{array}$ & $\begin{array}{l}17 \\
3 \\
5 \\
3 \\
4 \\
2 \\
1\end{array}$ & $\begin{array}{c}48.6 \\
8.6 \\
14.3 \\
8.6 \\
11.4 \\
5.7 \\
2.9 \\
\end{array}$ & $\begin{array}{l}15 \\
5 \\
5 \\
1 \\
6 \\
1 \\
2 \\
\end{array}$ & $\begin{array}{c}42.9 \\
14.3 \\
14.3 \\
2.9 \\
17.1 \\
2.9 \\
5.7 \\
\end{array}$ & 2.860 & $\begin{array}{l}{ }_{\mathrm{p}}^{\mathrm{MC}}= \\
0.870\end{array}$ \\
\hline $\begin{array}{l}\text { Cohabitation } \\
\text { Alone } \\
\text { with spouse } \\
\text { with family } \\
\text { with relatives }\end{array}$ & $\begin{array}{c}3 \\
7 \\
22 \\
3 \\
\end{array}$ & $\begin{array}{c}8.6 \\
20.0 \\
62.9 \\
8.6 \\
\end{array}$ & $\begin{array}{c}1 \\
6 \\
26 \\
2 \\
\end{array}$ & $\begin{array}{c}2.9 \\
17.1 \\
74.3 \\
5.7 \\
\end{array}$ & 1.640 & $\begin{array}{l}{ }^{\mathrm{MC}}= \\
0.687\end{array}$ \\
\hline $\begin{array}{l}\text { Family size } \\
<4 \\
4-6 \\
\geq 7\end{array}$ & $\begin{array}{c}14 \\
17 \\
4 \\
\end{array}$ & $\begin{array}{l}40.0 \\
48.6 \\
11.4\end{array}$ & $\begin{array}{c}12 \\
20 \\
3\end{array}$ & $\begin{array}{c}34.3 \\
57.1 \\
8.6\end{array}$ & 0.607 & $\begin{array}{l}{ }^{\mathrm{MC}}= \\
0.779\end{array}$ \\
\hline $\begin{array}{l}\text { Income } \\
\text { Insufficient } \\
\text { Sufficient } \\
\text { More than sufficient }\end{array}$ & $\begin{array}{c}26 \\
6 \\
3 \\
\end{array}$ & $\begin{array}{c}74.3 \\
17.1 \\
8.6 \\
\end{array}$ & $\begin{array}{c}25 \\
8 \\
2 \\
\end{array}$ & $\begin{array}{c}71.4 \\
22.9 \\
5.7 \\
\end{array}$ & 0.590 & 0.853 \\
\hline $\begin{array}{l}\text { Source of income } \\
\text { Work } \\
\text { Family } \\
\text { Social help } \\
\end{array}$ & $\begin{array}{c}16 \\
14 \\
5 \\
\end{array}$ & $\begin{array}{l}45.7 \\
40.0 \\
14.3 \\
\end{array}$ & $\begin{array}{c}16 \\
14 \\
5 \\
\end{array}$ & $\begin{array}{l}45.7 \\
40.0 \\
14.3 \\
\end{array}$ & 0.00 & 1.000 \\
\hline $\begin{array}{l}\text { Type of department } \\
\text { Free } \\
\text { Paid } \\
\end{array}$ & $\begin{array}{l}25 \\
10 \\
\end{array}$ & $\begin{array}{l}71.4 \\
28.6 \\
\end{array}$ & $\begin{array}{l}25 \\
10 \\
\end{array}$ & $\begin{array}{l}71.4 \\
28.6 \\
\end{array}$ & 0.00 & 1.000 \\
\hline
\end{tabular}

$\chi^{2}$ : Chi square test

MC: Monte Carlo

$\mathrm{p}: \mathrm{p}$ value for comparing between the studied groups 
Table (2): Clinical data of study subjects with schizophrenia and their control group

\begin{tabular}{|c|c|c|c|c|c|c|}
\hline \multirow[t]{2}{*}{ Clinical characteristics } & \multicolumn{2}{|c|}{$\begin{array}{l}\text { Study } \\
(n=35)\end{array}$} & \multicolumn{2}{|c|}{$\begin{array}{c}\text { Control } \\
(n=35)\end{array}$} & \multirow[t]{2}{*}{$\chi^{2}$} & \multirow[t]{2}{*}{$\mathbf{p}$} \\
\hline & No. & $\%$ & No. & No. & & \\
\hline $\begin{array}{l}\text { Duration of psychiatric disorder } \\
<2 \text { years } \\
2-5 \text { years } \\
>5 \text { years }\end{array}$ & $\begin{array}{c}6 \\
16 \\
13\end{array}$ & $\begin{array}{l}17.1 \\
45.7 \\
37.1\end{array}$ & $\begin{array}{c}8 \\
15 \\
12\end{array}$ & $\begin{array}{l}22.9 \\
42.9 \\
34.3\end{array}$ & 0.358 & 0.836 \\
\hline $\begin{array}{l}\text { Duration of current hospitalization } \\
<2 \text { weeks } \\
2 \text { weeks- } 1 \text { month }\end{array}$ & $\begin{array}{l}23 \\
12\end{array}$ & $\begin{array}{l}65.7 \\
34.3\end{array}$ & $\begin{array}{l}25 \\
10\end{array}$ & $\begin{array}{l}71.4 \\
28.6\end{array}$ & 0.265 & 0.607 \\
\hline $\begin{array}{l}\text { Duration of treatment with psychotropic } \\
\text { medications ( } \text { years) } \\
<2 \text { years } \\
2 \text { years }<5 \text { years } \\
5 \text { years }<8 \text { years } \\
\geq 8 \text { years }\end{array}$ & $\begin{array}{c}8 \\
18 \\
8 \\
1\end{array}$ & $\begin{array}{c}22.9 \\
51.4 \\
22.9 \\
2.9\end{array}$ & $\begin{array}{c}10 \\
15 \\
9 \\
1\end{array}$ & $\begin{array}{c}28.6 \\
42.9 \\
25.7 \\
2.9\end{array}$ & 0.838 & $\begin{array}{l}{ }_{\mathrm{p}}^{\mathrm{MC}}= \\
0.907\end{array}$ \\
\hline $\begin{array}{l}\text { Number of psychiatric hospitalization } \\
\text { None } \\
1<3 \text { times } \\
3<6 \text { times } \\
\geq 6 \text { times }\end{array}$ & $\begin{array}{c}2 \\
10 \\
14 \\
9\end{array}$ & $\begin{array}{c}5.7 \\
28.6 \\
40.0 \\
25.7 \\
\end{array}$ & $\begin{array}{c}3 \\
8 \\
15 \\
9\end{array}$ & $\begin{array}{c}8.6 \\
22.9 \\
42.9 \\
25.7 \\
\end{array}$ & 0.575 & $\begin{array}{l}{ }^{\mathrm{MC}} \mathrm{p}= \\
0.967\end{array}$ \\
\hline $\begin{array}{l}\text { Symptoms on admission: } * \\
\text { Delusions } \\
\text { Hallucinations } \\
\text { Excitement } \\
\text { Suicidal ideation } \\
\text { Mood changes }\end{array}$ & $\begin{array}{c}23 \\
26 \\
21 \\
6 \\
15 \\
\end{array}$ & $\begin{array}{l}65.7 \\
74.3 \\
60.0 \\
17.1 \\
42.9 \\
\end{array}$ & $\begin{array}{c}23 \\
27 \\
17 \\
7 \\
16\end{array}$ & $\begin{array}{l}65.7 \\
77.1 \\
48.6 \\
20.0 \\
45.7 \\
\end{array}$ & $\begin{array}{c}0.00 \\
0.078 \\
0.921 \\
0.094 \\
0.058\end{array}$ & $\begin{array}{l}1.000 \\
0.780 \\
0.337 \\
0.759 \\
0.810 \\
\end{array}$ \\
\hline $\begin{array}{l}\text { Time lapsed from last discharge } \\
\text { No } \\
<6 \text { months } \\
6 \text { months-1year } \\
>1 \text { year }\end{array}$ & $\begin{array}{c}2 \\
15 \\
13 \\
5\end{array}$ & $\begin{array}{c}5.7 \\
42.9 \\
37.1 \\
14.3 \\
\end{array}$ & $\begin{array}{c}3 \\
13 \\
18 \\
1\end{array}$ & $\begin{array}{c}8.6 \\
37.1 \\
51.4 \\
2.9\end{array}$ & 3.705 & $\begin{array}{l}{ }^{\mathrm{MC}} \mathrm{p}= \\
0.284\end{array}$ \\
\hline $\begin{array}{l}\text { Medications currently prescribed for the } \\
\text { patient } \\
\text { Typical antipsychotics } \\
\text { Atypical antipsychotics } \\
\text { Mixed antipsychotics }\end{array}$ & $\begin{array}{c}17 \\
11 \\
7 \\
\end{array}$ & $\begin{array}{l}48.6 \\
31.4 \\
20.0 \\
\end{array}$ & $\begin{array}{c}18 \\
11 \\
6 \\
\end{array}$ & $\begin{array}{l}51.4 \\
31.4 \\
17.1 \\
\end{array}$ & 0.105 & 0.949 \\
\hline
\end{tabular}


Table (3): Mean scores obtained in total social functioning scale and its subscales in study subjects with schizophrenia and their control groups at pre and post study intervention

\begin{tabular}{|c|c|c|c|c|c|c|c|c|}
\hline \multirow{2}{*}{$\begin{array}{l}\text { The social } \\
\text { functioning scale }\end{array}$} & \multicolumn{2}{|c|}{ Study $(n=35)$} & \multirow{2}{*}{$\mathbf{z}_{\mathbf{p}_{3}}$} & \multicolumn{2}{|c|}{ Control $(n=35)$} & \multirow{2}{*}{$\mathrm{z}_{\mathrm{p}_{4}}$} & \multirow{2}{*}{$\mathbf{U}\left(\mathbf{p}_{1}\right)$} & \multirow{2}{*}{$\mathbf{U}\left(\mathbf{p}_{2}\right)$} \\
\hline & Pre & Post & & Pre & Post & & & \\
\hline $\begin{array}{l}\text { Withdrawal/Social } \\
\text { Engagement } \\
\text { Min. - Max. } \\
\text { Mean } \pm \text { SD. }\end{array}$ & $\begin{array}{c}1.0-15.0 \\
7.74 \pm 3.83\end{array}$ & $\begin{array}{c}2.0-15.0 \\
10.31 \pm 3.38\end{array}$ & $<0.001^{*}$ & $\begin{array}{c}1.0-14.0 \\
8.20 \pm 3.75\end{array}$ & $\begin{array}{c}2.0-14.0 \\
8.66 \pm 3.63\end{array}$ & 0.071 & $\begin{array}{l}578.50 \\
(0.688) \\
\end{array}$ & $\begin{array}{l}444.00^{*} \\
\left(0.047^{*}\right)\end{array}$ \\
\hline $\begin{array}{l}\text { Interpersonal } \\
\text { Communication } \\
\text { Min. - Max. } \\
\text { Mean } \pm \text { SD. }\end{array}$ & $\begin{array}{c}1.0-9.0 \\
4.83 \pm 2.74\end{array}$ & $\begin{array}{c}0.0-9.0 \\
6.23 \pm 2.50\end{array}$ & $<0.001^{*}$ & $\begin{array}{c}0.0-9.0 \\
4.66 \pm 2.53\end{array}$ & $\begin{array}{c}0.0-9.0 \\
4.91 \pm 2.58\end{array}$ & 0.279 & $\begin{array}{l}588.00 \\
(0.772) \\
\end{array}$ & $\begin{array}{l}434.50^{*} \\
\left(0.035^{*}\right)\end{array}$ \\
\hline $\begin{array}{l}\text { Independence- } \\
\text { Performance } \\
\text { Min. - Max. } \\
\text { Mean I SD. }\end{array}$ & $\begin{array}{c}6.0-34.0 \\
18.77 \pm 8.52\end{array}$ & $\begin{array}{c}6.0-35.0 \\
23.06 \pm 7.98\end{array} \mid$ & $<0.001^{*}$ & $\begin{array}{c}8.0-36.0 \\
21.37 \pm 8.77\end{array}$ & $\begin{array}{c}6.0-37.0 \\
21.20 \pm 9.02\end{array}$ & 0.538 & $\begin{array}{l}507.00 \\
(0.215) \\
\end{array}$ & $\begin{array}{l}524.00 \\
(0.298) \\
\end{array}$ \\
\hline $\begin{array}{l}\text { Independence- } \\
\text { Competence } \\
\text { Min. - Max. } \\
\text { Mean I SD. }\end{array}$ & $\begin{array}{c}8.0-36.0 \\
21.71 \pm 7.31\end{array}$ & $\left|\begin{array}{c}11.0-37.0 \\
28.34 \pm 6.61\end{array}\right|$ & $<0.001^{*}$ & $\begin{array}{r}12.0-36.0 \\
23.66 \pm 6.73\end{array}$ & $\mid \begin{array}{c}13.0-37.0 \\
24.77 \pm 6.83\end{array}$ & $0.015^{*}$ & $\begin{array}{l}521.50 \\
(0.284)\end{array}$ & $\begin{array}{l}422.50^{*} \\
\left(0.025^{*}\right)\end{array}$ \\
\hline $\begin{array}{l}\text { Recreation } \\
\text { Min. - Max. } \\
\text { Mean } \pm \text { SD. }\end{array}$ & $\begin{array}{c}6.0-32.0 \\
16.66 \pm 7.48 \\
\end{array}$ & $\begin{array}{c}5.0-33.0 \\
19.54 \pm 7.83\end{array}$ & $0.002^{*}$ & $\begin{array}{c}5.0-34.0 \\
16.29 \pm 8.62 \\
\end{array}$ & $\begin{array}{c}3.0-36.0 \\
15.80 \pm 8.15\end{array}$ & 0.228 & $\begin{array}{l}580.00 \\
(0.702) \\
\end{array}$ & $\begin{array}{l}438.00^{*} \\
\left(0.040^{*}\right) \\
\end{array}$ \\
\hline $\begin{array}{l}\text { Pro social } \\
\text { Total score } \\
\text { Min. - Max. } \\
\text { Mean } \pm \text { SD. } \\
\end{array}$ & $\begin{array}{c}3.0-52.0 \\
22.46 \pm 14.43\end{array}$ & $\begin{array}{c}10.0-53.0 \\
29.29 \pm 12.72\end{array}$ & $<0.001^{*}$ & $\begin{array}{c}4.0-54.0 \\
24.26 \pm 14.3\end{array}$ & $\begin{array}{c}4.0-49.0 \\
22.54 \pm 11.23\end{array}$ & 0.128 & $\begin{array}{l}558.00 \\
(0.522) \\
\end{array}$ & $\begin{array}{l}433.50^{*} \\
\left(0.035^{*}\right) \\
\end{array}$ \\
\hline $\begin{array}{l}\text { Employment/Occup } \\
\text { ation } \\
\text { Min. - Max. } \\
\text { Mean } \pm \text { SD. } \\
\end{array}$ & $\begin{array}{c}0.0-10.0 \\
5.54 \pm 3.53\end{array}$ & $\begin{array}{c}0.0-10.0 \\
6.09 \pm 3.13 \\
\end{array}$ & $0.026^{*}$ & $\begin{array}{c}0.0-10.0 \\
5.86 \pm 3.57 \\
\end{array}$ & $\begin{array}{c}1.0-10.0 \\
5.80 \pm 3.18 \\
\end{array}$ & 0.729 & $\begin{array}{l}569.00 \\
(0.607) \\
\end{array}$ & $\begin{array}{l}562.00 \\
(0.549) \\
\end{array}$ \\
\hline $\begin{array}{l}\text { Global social } \\
\text { functioning scale } \\
\text { Min. - Max. } \\
\text { Mean } \pm \text { SD. }\end{array}$ & $\left|\begin{array}{l}39.0-182.0 \\
97.71 \pm 42.62\end{array}\right|$ & $\begin{array}{l}46.0-188.0 \\
121.9 \pm 40.77\end{array}$ & $<0.001^{*}$ & $\begin{array}{l}37.0-176.0 \\
104.3 \pm 43.35\end{array}$ & $\left|\begin{array}{l}38.0-171.0 \\
101.3 \pm 37.75\end{array}\right|$ & 0.249 & $\begin{array}{l}551.00 \\
(0.470)\end{array}$ & $\begin{array}{l}432.50^{*} \\
\left(0.034^{*}\right)\end{array}$ \\
\hline
\end{tabular}

\section{U: Mann Whitney test Z: Wilcoxon signed ranks test}

$p_{1}: p$ value for comparing between study and control group in pre period

$p_{2}: p$ value for comparing between study and control group in post period

$p_{3}: p$ value for comparing between pre and post in study group

$p_{4}: p$ value for comparing between pre and post in control group

*: Statistically significant at $p \leq 0.05$ 
Physical Exercise, Psychotic Symptoms, Social Functioning

Table (4): Comparison between the studied and control groups according to positive symptoms group on brief psychiatric rating scale (BPRS) at pre and post study intervention

\begin{tabular}{|c|c|c|c|c|c|c|c|c|c|c|c|}
\hline \multirow{2}{*}{$\begin{array}{l}\text { Brief psychiatric rating scale } \\
\text { (BPRS) }\end{array}$} & \multicolumn{3}{|c|}{$\operatorname{Study}(\mathrm{n}=3 \mathbf{5})$} & \multirow{2}{*}{${ }^{\mathrm{Fr}} \mathrm{p}_{4}$} & \multicolumn{3}{|c|}{ Control(n = 35) } & \multirow{2}{*}{${ }^{\mathrm{Fr}} \mathrm{p}_{4}$} & \multirow{2}{*}{$\mathrm{U}\left(\mathrm{p}_{1}\right)$} & \multirow{2}{*}{$\mathrm{U}\left(\mathrm{p}_{2}\right)$} & \multirow{2}{*}{$\mathrm{U}\left(\mathrm{p}_{3}\right)$} \\
\hline & Pre & $\begin{array}{c}\text { Immediately } \\
\text { post }\end{array}$ & Post & & Pre & $\begin{array}{c}\text { Immediately } \\
\text { post }\end{array}$ & Post & & & & \\
\hline Positive symptoms group & & & & & & & & & & & \\
\hline Min. - Max. & $10.0-36.0$ & $8.0-28.0$ & $7.0-32.0$ & $<0.001^{*}$ & $8.0-35.0$ & & & 0.336 & $595.50(0.841)$ & $412.0^{*}\left(0.018^{*}\right)$ & $439.50^{*}\left(0.042^{*}\right)$ \\
\hline Mean \pm SD. & $20.06 \pm 7.54$ & $16.23 \pm 6.17$ & $16.91 \pm 6.82$ & & $19.60 \pm 7.28$ & $20.29 \pm 7.07$ & $20.09 \pm 6.25$ & & & & \\
\hline Grandiosity & $3.91 \pm 2.03$ & $3.14 \pm 2.02$ & $3.31 \pm 2.01$ & $0.028^{*}$ & $3.77 \pm 2.09$ & $4.17 \pm 1.89$ & $4.29 \pm 2.07$ & 0.097 & $590.50(0.792)$ & $438.50^{*}\left(0.036^{*}\right)$ & $445.0^{*}\left(0.044^{*}\right)$ \\
\hline Bizarre behavior & $2.06 \pm 1.57$ & $1.29 \pm 0.79$ & $1.54 \pm 0.92$ & $<0.001^{*}$ & $1.89 \pm 1.23$ & $1.80 \pm 1.18$ & $1.80 \pm 0.99$ & 0.529 & $600.0(0.868)$ & $477.50^{*}\left(0.043^{*}\right)$ & $510.0(0.167)$ \\
\hline Unusual thought content & $3.91 \pm 2.09$ & $3.09 \pm 1.70$ & $3.49 \pm 1.88$ & $<0.001^{*}$ & $4.17 \pm 1.98$ & $4.37 \pm 2.33$ & $4.60 \pm 1.68$ & 0.545 & $567.50(0.586)$ & $387.0^{*}\left(0.007^{*}\right)$ & $393.0^{*}\left(0.008^{*}\right)$ \\
\hline Disorientation & $1.34 \pm 0.73$ & $1.29 \pm 0.62$ & $1.17 \pm 0.62$ & 0.102 & $1.20 \pm 0.53$ & $1.20 \pm 0.53$ & $1.20 \pm 0.58$ & 1.000 & $559.50(0.358)$ & $577.0(0.525)$ & $596.0(0.710)$ \\
\hline Hallucinations & $3.29 \pm 1.78$ & $2.26 \pm 1.31$ & $2.60 \pm 1.46$ & $<0.001^{*}$ & $3.37 \pm 1.72$ & $3.40 \pm 1.74$ & $3.06 \pm 1.39$ & $<0.001^{*}$ & $592.0(0.806)$ & $380.0^{*}\left(0.005^{*}\right)$ & $506.0(0.197)$ \\
\hline Suspiciousness & $4.06 \pm 2.06$ & $3.46 \pm 2.25$ & $3.14 \pm 1.85$ & $0.037^{*}$ & $3.54 \pm 2.16$ & $3.69 \pm 2.15$ & $3.31 \pm 1.68$ & $0.001^{*}$ & $532.0(0.328)$ & $577.50(0.667)$ & $561.0(0.537)$ \\
\hline Conceptual disorganization & $1.49 \pm 0.82$ & $1.71 \pm 0.93$ & $1.66 \pm 0.87$ & 0.276 & $1.66 \pm 1.03$ & $1.66 \pm 1.03$ & $1.83 \pm 1.01$ & 0.103 & $577.50(0.621)$ & $575.50(0.618)$ & $567.0(0.543)$ \\
\hline
\end{tabular}

U: Mann Whitney test

Fr: Friedman test

$p_{1}: p$ value for comparing between study and control group in pre period

$p_{2}: p$ value for comparing between study and control group in imm post period

$p_{3}: p$ value for comparing between study and control group in post period

p: $p$ value for comparing between pre, immediate post and after 3 months in study group

$p_{5:}$ p value for comparing between pre, immediate post and after 3 months in control group

$*$ : Statistically significant at $p \leq 0.05$ 
Physical Exercise, Psychotic Symptoms, Social Functioning

Table (5): Comparison between the studied and control groups according to negative symptoms group on brief psychiatric rating scale (BPRS) at pre and post study intervention

\begin{tabular}{|c|c|c|c|c|c|c|c|c|c|c|c|}
\hline \multirow{2}{*}{$\begin{array}{l}\text { Brief psychiatric rating } \\
\text { scale (BPRS) }\end{array}$} & \multicolumn{3}{|c|}{$\operatorname{Study}(\mathrm{n}=\mathbf{3 5})$} & \multirow{2}{*}{${ }^{\mathrm{F}} \mathrm{p}_{4}$} & \multicolumn{3}{|c|}{$\operatorname{Control}(\mathrm{n}=35)$} & \multirow{2}{*}{${ }^{\mathrm{F}} \mathrm{p}_{5}$} & \multirow{2}{*}{$\mathrm{U}\left(\mathrm{p}_{1}\right)$} & \multirow{2}{*}{$\mathrm{U}\left(\mathrm{p}_{2}\right)$} & \multirow{2}{*}{$\mathrm{U}\left(\mathrm{p}_{3}\right)$} \\
\hline & Pre & $\begin{array}{c}\text { Immediatel } \\
\text { y post }\end{array}$ & $\begin{array}{l}\text { After } 3 \\
\text { months }\end{array}$ & & Pre & $\begin{array}{c}\text { Immediatel } \\
\text { y post }\end{array}$ & $\begin{array}{l}\text { After } 3 \\
\text { months }\end{array}$ & & & & \\
\hline $\begin{array}{l}\text { Negative symptoms group } \\
\text { Min. - Max. } \\
\text { Mean } \pm \text { SD. }\end{array}$ & $\begin{array}{l}3.0-13.0 \\
6.43 \pm 3.04\end{array}$ & $\begin{array}{l}3.0-10.0 \\
5.60 \pm 2.28\end{array}$ & $\begin{array}{l}3.0-10.0 \\
5.29 \pm 2.18\end{array}$ & $0.003^{*}$ & $\begin{array}{l}3.0-12.0 \\
6.66 \pm 2.62\end{array}$ & $\begin{array}{l}3.0-12.0 \\
6.83 \pm 2.63\end{array}$ & $\begin{array}{l}3.0-12.0 \\
6.89 \pm 2.40\end{array}$ & 0.302 & $564.50(0.570)$ & $449.50(0.053)$ & $\begin{array}{l}375.50^{*} \\
\left(0.005^{*}\right)\end{array}$ \\
\hline Blunted affect & $2.97 \pm 1.64$ & $2.66 \pm 1.28$ & $2.43 \pm 1.07$ & $0.004^{*}$ & $2.94 \pm 1.43$ & $2.86 \pm 1.44$ & $3.06 \pm 1.30$ & 0.117 & $603.0(0.909)$ & $566.50(0.580)$ & $\begin{array}{l}437.0^{*} \\
\left(0.033^{*}\right)\end{array}$ \\
\hline Emotional withdrawal & $2.14 \pm 1.46$ & $1.71 \pm 1.05$ & $1.74 \pm 1.09$ & $0.034^{*}$ & $2.11 \pm 1.18$ & $2.37 \pm 1.26$ & $2.26 \pm 1.09$ & 0.237 & $584.0(0.723)$ & $426.50^{*}\left(0.019^{*}\right)$ & $\begin{array}{l}441.50^{*} \\
\left(0.031^{*}\right)\end{array}$ \\
\hline Motor retardation & $1.31 \pm 0.63$ & $1.23 \pm 0.55$ & $1.11 \pm 0.47$ & $0.021^{*}$ & $1.60 \pm 0.88$ & $1.60 \pm 0.88$ & $1.57 \pm 0.88$ & 1.000 & $515.0(0.156)$ & $481.0^{*}\left(0.048^{*}\right)$ & $\begin{array}{l}441.50^{*} \\
\left(0.004^{*}\right)\end{array}$ \\
\hline
\end{tabular}

U: Mann Whitney test

Fr: Friedman test

$p_{1}:$ p value for comparing between study and control group in pre period

p2: p value for comparing between study and control group in imm post period

$p_{3}: p$ value for comparing between study and control group in post period

p: $p$ value for comparing between pre, immediate post and after 3 months in study group

$p_{5:}: p$ value for comparing between pre, immediate post and after 3 months in control group

$*$ : Statistically significant at $p \leq 0.05$ 


\section{References}

1. American Psychiatric Association. Diagnostic and Statistical Manual of Mental Disorders. 4th ed. Washington: American Psychiatric Press, 1994; 248-60.

2. Zahran N. Systematic review of Egyptian studies. Published Master Thesis: Faculty of Medicine, Ain Shams University, 2006. Available at: http://psychiatry-research-eg.com.

3. American Psychiatric Association. Diagnostic and statistical manual of mental disorders. 5th ed. Arlington: American Psychiatric Association, 2013.

4. World Health Organization. ICD-10 Classification of mental and behavioural disorders. Clinical descriptions and diagnostic guidelines. Geneva: World Health Organization, 2018.

5. Dodell-Feder D, Tully LM, Hooker CI. Social impairment in schizophrenia: New approaches for treating a persistent problem. Current Opinion in Psychiatry 2015; 28(3): 236- 42.

6. Brissos S, Molodynski A,Videira Dias V, Luísa Figueira M. The importance of measuring psychosocial functioning in schizophrenia. Annals of General Psychiatry 2011; 10: 18.

7. Vedana KG, Miasso AI. The meaning of pharmacological treatment for schizophrenic patients. Revista Latino-Americana de Enfermagem 2014; 22(4): 670-8.

8. Holmes L. Antipsychotic Medications, 2018. Available at: https://www.verywellmind.com/antipsychoticmedications-2330662. Retrieved on: $(28 / 6 / 2019)$.

9. Scheewe TW, Backx FJG, Takken T, Jorg F, van Strater ACP, Kroes AG, Kahn RS, Cahn W. Exercise therapy improves mental and physical health in schizophrenia: a randomised controlled trial. Acta Psychiatrica Scandinavica 2013: 127: 464- 73 .

10. Lindamer LA, McKibbin C, Norman GJ, Jordan L, Harrison K, Abeyesinhe S, Patrick K. Assessment of physical activity in middle-aged and older adults with schizophrenia. Schizophrenia Research 2008; 104: 294-301.

11. Deslandes A, Moraes H, Ferreira C, Veiga H, Silveira H, Mouta R, Pompeu FA, Coutinho ES, Laks J. Exercise and mental health: many reasons to move. Neuropsychobiology 2009; 59: 191-8.
12. Jerstad SJ, Boute KN, Ness KK, Stice E. Prospective reciprocal relations between physical activity and depression in female adolescents. Journal of Consulting and Clinical Psychology 2010; 78(2): 268-72.

13. Faulkner G, Carless D. Physical activity in the process of psychiatric rehabilitation: theoretical and methodological issues. Psychiatric Rehabilitation Journal 2006; 29(4): 258.

14. Fogarty M, Happell B. Exploring the benefits of an exercise program for people with schizophrenia: A qualitative study. Issues in mental health nursing 2005; 26(3): 341-51.

15. Happell B, Scott D, Platania-Phung C, Nankivell J. Nurses views on physical activity for people with serious mental illness. Mental Health and Physical Activity 2012; 5: 4-12.

16. Ventura J, Lukoff D, Nuechterlein K, Liberman R, Green M, Shaner A. Appendix 1: Brief Psychiatric Rating Scale (BPRS) Expanded version (4.0) scales, anchor points and administration manual. International Journal of Methods in Psychiatric 1993; 3: 227-44.

17. Morosini $\mathrm{P}$, Roncone $\mathrm{R}$, Impallomeni $\mathrm{M}$, Marola V, Casacchia M. Presentazione dell'adattamento italiano della Brief Psychiatric Rating Scale, versione 4.0 ampliata (BPRS 4.0) Rivista di Riabilitazione Psichiatrica e Psicosociale 1995; 3: 195-98.

18. Kopelowicz A, Ventura J, Liberman R, Mintz J. Consistency of Brief Psychiatric Rating Scale Factor Structure across a Broad Spectrum of Schizophrenia Patients. Psychopathology 2008; 41: 77-84.

19. Birchwood M, Smith J, Cochrane R, Wetton S, Copestake S. The Social Functioning Scale. The development and validation of a new scale of social adjustment for use in family intervention programmes with schizophrenic patients. The British Journal of Psychiatry 1990; 157: 853-9.

20. Atta M. Dimensions of Emotional Regulation Difficulties and Areas of Social Functioning among Patients with Schizophrenia. Unpublished Master Thesis. Faculty of Nursing, Alexandria University, 2017.

21. Elnakeeb M. The relationship of social cognition and psychotic symptoms with social functioning of schizophrenic patients. Unpublished Doctorate Thesis. Faculty of Nursing, Alexandria University, 2013.

22. Tas C. Understanding social functioning in schizaophrenia. Published dissertation. 
International Graduate School of Neuroscience.Ruhr University, 2013.

23. Shim G, Kang D, Chung Y, Yoo SY. Social functioning deficits in young people at risk for schizophrenia. Australian and New Zealand Journal of Psychiatry 2008; 42:678-85.

24. Scemes S, Silvia A, Elkis H, Savoia M, Prette Z. Social dysfunction and skills in schizophrenia: relationship with treatment response and severity of psychopathology. Archives of Clinical Psychiatry (Sao Paulo) 2016; 43(5): 107-11.

25. Capasso RM, Lineberry TW, Bostwick JM, et al. Mortality in schizophrenia and schizoaffective disorder: an Olmsted County. Schizophrenia Research 2008; 98: 287-94.

26. Malchow B, Reich-Erkelenz D,Oertel-Knochel V, Keller K, Hasan A, Schmitt A, Scheewe TW, Cahn W, Kahn R, Falkai P. The effects of physical exercise in schizophrenia and affective disorders. European Archives of Psychiatry and Clinical Neuroscience 2013; 263: 451-67.

27. Pajonk FG, Wobrock T, Gruber O. Hippocampal plasticity in response to exercise in schizophrenia. Archives of General Psychiatry 2010; 67:133-43.

28. Kwon JS, Choi JS, Bahk WM et al. Weight management program for treatment-emergent weight gain in olanzapine treated patients with schizophrenia or schizoaffective disorder: a 12week randomised controlled clinical trial. Journal of Clinical Psychiatry 2006; 67: 54753.

29. Heggelund J, Nilsberg GE, Hoff J, Morken G, Helgerud J. Effects of high aerobic intensity training in patients with schizophrenia: a controlled trial. Nordic Journal of Psychiatry 2011; 65: 269-75.

30. Firth J, Cotter J, Elliott R, French P, Yung AR. A systematic review and meta-analysis of exercise interventions in schizophrenia patients. Psychological Medicine 2015; 45: 1343-61.

31. Kimhy Lauriola V, Bartels MN, Armstrong HF, Vakhrusheva J, Ballon JS, Sloan RP. Aerobic exercise for cognitive deficits in schizophrenia the impact of frequency, duration, and fidelity with target training intensity. Schizophrenia Research 2016; 172: 213-15.

32. Kandola A, JHendrikse J, Lucassen PJ, Yücel M. Aerobic exercise as a tool to improve hippocampal plasticity and function in humans: practical implications for mental health treatment. Frontiers in Human Neuroscience 2016; 10 (373).
33. Stranahan AM, Lee K, Mattson MP. Central mechanisms of HPA axis regulation by voluntary exercise. NeuroMolecular Medicine 2008; 10: 118-27.

34. Vina J, Sanchis-Gomar F, Martinez-Bello V, Gomez-Cabrera MC. Exercise acts as a drug; the pharmacological benefits of exercise. British Journal of Pharmacology 2012; 167:112.

35. Khazaeinia T, Ramsey AA, Tam YK. The effects of exercise on the pharmacokinetics of drugs. Journal of Pharmacy \& Pharmaceutical Sciences 2000; 3:292-302.

36. Burton N. Living with Schizophrenia. Acheron Press 2012: 90.

37. Wang PW, Lin HC, Su CY, Chen MD, Lin KC, $\mathrm{Ko} \mathrm{CH}$, Yen CF. Effect of Aerobic Exercise on Improving Symptoms of Individuals With Schizophrenia: A Single Blinded Randomized Control Study.Frontiers in Psychiatry 2018; 9: 167.

38. Dauwan M, Begemann MJ, Heringa SM, Sommer IE. Exercise improves clinical symptoms, quality of life, global functioning, and depression in schizophrenia: a systematic review and meta-analysis. Schizophrenia Bulletin 2016; 42: 588-99.

39. Rosenbaum S, Tiedemann A, Sherrington C, Curtis J, Ward PB. Physical activity interventions for people with mental illness: a systematic review and meta-analysis. Journal of Clinical Psychiatry 2014; 75: 964-74.

40. Millan MJ, Fone K, Steckler T, Horan WP. Negative symptoms of schizophrenia: clinical characteristics, physiological substrates, experimental models and prospects for improved treatment. European Neuropsychopharmacology 2014; 24: 645- 92.

41. Vogel JS, Van Der Gaag M, Knegtering H, Castelein S. Effects of aerobic exercise on negative symptoms in schizophrenia: a metaanalysis. European Psychiatry 2015; 30: 927.

42. Lutgens D, Gariepy G, Malla A.Psychological and psychosocial interventions for negative symptoms in psychosis: systematic review and meta-analysis. British Journal of Psychiatry 2017; 210: 324-32. 